\title{
Analisis Kesalahan Siswa dalam Pemecahan Masalah Turunan Fungsi Aljabar
}

\author{
Broto Apriliyanto \\ SMA Negeri 1 Wuryantoro Kab. Wonogiri \\ Email: apriliyanto.broto@gmail.com
}

\begin{abstract}
Abstrak
Penelitian ini bertujuan untuk mengetahui kesalahan yang dilakukan siswa dalam pemecahan masalah pada materi Turunan fungsi. Penelitian ini dilaksanakan di SMA Negeri 1 Wuryantoro pada semester genap tahun pelajaran 2018/2019 dengan subyek penelitian sebanyak 20 siswa. Penelitian ini adalah penelitian deskriptif kualitatif dengan teknik pengumpulan datanya observasi, analisis hasil kerja dan wawancara. Hasil penelitian ini adalah kesalahan yang dilakukan siswa pada tahap memahami masalah $7,5 \%$, kesalahan tahap merencanakan penyelesaian $12,5 \%$, kesalahan tahap menyelesaikan masalah $55 \%$, dan kesalahan tahap pengecekan kembali 100\%. Berdasarkan tipe kesalahan diperoleh bahwa siswa melakukan kesalahan fakta 27,5\%, kesalahan konsep 42,5\%, kesalahan prinsip 37,5\%, dan kesalahan operasi 22,5\%. Solusi yang ditawarkan yaitu siswa harus dibiasakan untuk lebih teliti dalam menyelesaikan soal sesuai tahapan pemecahan masalah, khususnya pengecekan kembali serta memperdalam kemampuan dasar operasi aljabar dan pemfaktoran.
\end{abstract}

Kata-kata kunci: Analisis Kesalahan, Pemecahan Masalah, Turunan fungsi Aljabar

\section{Students’ Error Analysis in Problem Solving of Algebraic Derivative Function}

\section{Broto Apriliyanto}

State Senior High School 1 Wuryantoro, Wonogiri Regency

Email: apriliyanto.broto@gmail.com

\begin{abstract}
This study aims to determine the errors made by students in solving problems in the derivative function material. This research was conducted at State Senior High School 1 Wuryantoro in the second semester of the 2018/2019 academic year with 20 students as the research subjects. This research is descriptive qualitative research which use data collection techniques of observation, analysis of work results and interview. The results of this study are errors made by students at the stage of understanding the problem $7.5 \%$, planning the completion $12.5 \%$, resolving the problem $55 \%$, and rechecking $100 \%$. Based on the types of error, it was found that students made fact errors $27.5 \%$, conceptual errors $42.5 \%$, principle errors $37.5 \%$, and operating errors $22.5 \%$. The solution offered is that students must be accustomed to be more thorough in solving problems according to the stages of problem solving, especially rechecking and deepening the basic competence of algebraic and factoring operations.
\end{abstract}

Key words: Error Analysis, Problem Solving, Algebraic Derivative Function 


\section{PENDAHULUAN}

Keberhasilan pembelajaran siswa di sekolah dirumuskan dalam Kompetensi Dasar dan Kompetensi Inti yakni meliputi aspek sikap sosial dan spiritual, pengetahuan, dan ketrampilan. Di dalam Permendikbud Nomor 20 Tahun 2016 disebutkan bahwa lulusan SMA pada dimensi pengetahuan diharapkan memiliki pengetahuan faktual, konseptual, prosedural, dan metakognitif pada tingkat teknis, spesifik, detil, dan kompleks berkenaan dengan ilmu pengetahuan, teknologi, seni, budaya, dan humaniora. Siswa diharapkan ampu mengaitkan pengetahuan tersebut dalam konteks diri sendiri, keluarga, sekolah, masyarakat dan lingkungan alam sekitar, bangsa, negara, serta kawasan regional dan internasional. Di sisi lain, pada rumusan kompetensi sosial pada pembelajaran Matematika bahwa siswa diharapkan mampu menunjukkan sikap responsif, dan pro-aktif sebagai bagian dari solusi atas berbagai permasalahan. Hal ini selaras dengan tujuan pembelajaran Matematika yaitu belajar memecahkan masalah (problem solving). Menurut Widodo bahwa pemecahan masalah Matematika penting untuk diajarkan, karena dengan belajar memecahkan masalah, siswa tidak akan kehilangan makna dari mempelajari suatu konsep atau prinsip Matematika karena dapat mengapilkasikannya dalam menyelesaikan suatu masalah (Naisunis, 2018:108).

Berdasarkan hasil Programme for International Student Assessment (PISA) pada tahun 2015, Indonesia memperoleh skor 386 dan masih di bawah skor rata-rata international 490. Organization for Economic and Development (OECD) menyatakan bahwa Indonesia berada pada peringkat 63 dari 70 negara yang berpartisipasi dalam ajang PISA. Studi ini berkaitan dengan kemampuan matematika, membaca, dan sains pada siswa mengindikasikan bahwa siswa di Indonesia masih lemah dalam memodelkan dan menafsirkan masalah matematika ke dalam situsi nyata. Turunan Fungsi merupakan salah satu materi yang harus di tempuh siswa baik untuk program MIPA ataupun IPS karena termuat pada mata pelajaran Matematika Wajib. Berdasarkan analisis hasil kerja siswa dalam menyelesaikan soal Turunan, diketahui bahwa terdapat kesalahan-kesalahan yang dilakukan oleh siswa dalam melakukan operasi hitung aljabar, kesalahan dalam memfaktorkan suatu bentuk aljabar. Menurut Amir (2015) kesalahan merupakan suatu bentuk penyimpanan terhadap suatu kebenaran yang bersifat sistematis dan konsisten karena dipengaruhi oleh kompetensi siswa sedangkan kesalahan bersifat insidental karena terpengaruh hal lain di luar kompetensi siswa.

Analisis hasil kerja siswa dalam meyelesaikan soal Turunan fungsi aljabar menunjukkan terdapat beberapa kesalahan yang dilakukan oleh siswa. Kesalahan tersebut ditunjukkan pada Gambar 1. 


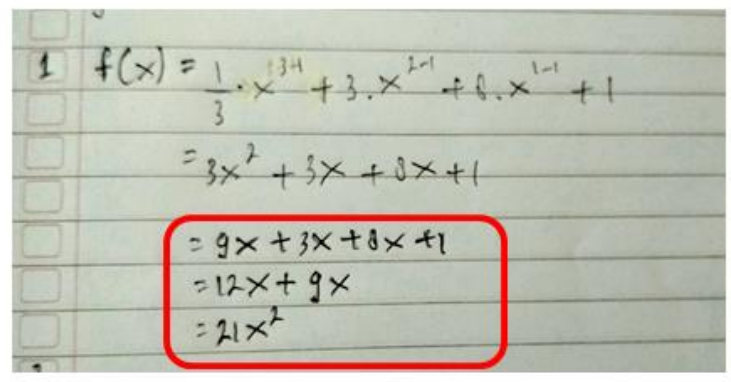

Gambar 1. Contoh kesalahan siswa dalam meyelesaikan soal turunan fungsi aljabar

Gambar 1 menunjukkan bahwa siswa melakukan kesalahan dalam mensubstitusikan nilai x pada fungsi yang menghasil bentuk bukan tak tentu sehingga siswa menyimpulkan bahwa hasil akhir adalah jawabannya. Kesalahan ini disebut kesalahan konsep dan juga kesalahan operasi, yaitu salah melakukan operasi hitung. Kesalahankesalahan siswa dalam pemecahan masalah perlu didentifikasi sehinga bisa dicari solusinya agar kesalahan yang sama tidak berlanjut. Informasi tentang kesalahan dalam memecahkan masalah dapat digunakan untuk meningkatkan kualitas pembelajaran dan hasil belajar siswa.
Dalam matematika, masalah yang dimaksudkan berupa soal yang meminta siswa untuk menyelesaikannya. Soal tersebut akan menjadi masalah jika siswa mempunyai motivasi untuk menyelesaikan tetapi tidak mempunyai ide atau aturan tertentu yang dapat digunakan untuk menyelesaikannya. Kesalahan dapat dikelompokkan menjadi 4 jenis, yaitu kesalahan fakta, kesalahan konsep, kesalahan prinsip, dan kesalahan operasi. Menurut Priansa (2014: 185) bahwa pemecahan masalah merupakan proses yang digunakan untuk menyelesaikan masalah. Pada penelitian ini tahapan pemecahan masalah yang digunakan adalah langkah pemecahan maslah dari Polya, yaitu tahap memahami masalah, merencanakan penyelesaian, menyelesaikan masalah, dan pengecekan kembali. Menurut Naisunis dkk (2018 : 109) berdasarkan langkah-langkah pemecahan masalah dari Polya, maka indikator kesalahan pada setiap langkah dapat diuraikan seperti pada Tabel 1.

Tabel 1. Indikator kesalahan sesuai dengan langkah Polya.

\begin{tabular}{lll}
\hline No. & Tahapan Langkah Polya & Indikator Kesalahan \\
\hline 1. & $\begin{array}{l}\text { Memahami masalah } \\
\text { (Kesalahan Tahap Pertama) }\end{array}$ & $\begin{array}{l}\text { 1. tidak mampu menentukan hal-hal yang diketahui } \\
\text { dan ditanyakan dalam soal, }\end{array}$ \\
& $\begin{array}{l}\text { 2. tidak dapat menceritakan kembali masalah yang } \\
\text { ada pada soal dengan bahasa sendiri }\end{array}$ \\
2. $\quad \begin{array}{l}\text { Merencanakan penyelesaian } \\
\text { (Kesalahan Tahap Kedua) }\end{array}$ & $\begin{array}{l}\text { 1. tidak mengetahu syarat cukup dan syarat perlu } \\
\text { dari suatu masalah }\end{array}$ \\
& $\begin{array}{l}\text { 2. tidak menggunakan semua informasi yang telah } \\
\text { dikumpulkan }\end{array}$ \\
3. $\begin{array}{l}\text { Menyelesaikan masalah } \\
\text { (Kesalahan Tahap Ketiga) }\end{array}$ & $\begin{array}{l}\text { 1. tidak menggunakan langkah penyelesaian dengan } \\
\text { benar }\end{array}$ \\
& $\begin{array}{l}\text { 2. tidak terampil dalam algoritma dan ketepatan } \\
\text { dalam menjawab soal }\end{array}$ \\
4. & $\begin{array}{l}\text { Pengecekan kembali } \\
\text { tidak melakukan pemeriksan kembali yang teah } \\
\text { dikerjakan }\end{array}$ \\
\hline
\end{tabular}


Tujuan dari penelitian ini adalah menganalis kesalahan yang dilakukan siswa dalam pemecahan masalah Turunan fungsi aljabar dan menawarkan ssolusi yang dapat diterapkan untuk mengurangi kesalahankesalahan siswa dalam menyelesaikan Turunan fungsi aljabar.

\section{METODE}

Penelitian ini adalah penelitian deskriptif kualitatif untuk menggambarkan dan menjelaskan secar rinci kesalahan siswa dalam memecahkan masalah pada materi Turunan fungsi aljabar. Penelitian ini dilaksanakan di SMA Negeri 1 Wuryantoro pada semester genap tahun pelajaran 2018/2019 dengan subjek penelitian 20 siswa.

Data penelitian ini berhubungan dengan kesalahan yang dilakukan siswa pada pemecahan masalah Turunan fungsi aljabar. Sumber data dalam penelitian ini adalah siswa yang mengikuti ulangan harian Turunan pekerjaan siswa berupa ulangan harian pada materi Turunan fungsi aljabar.

Pengumpulan data pada penelitian ini diperoleh melalui observasi, analisis hasil kerja siswa, dan wawancara. Observasi berupa kegiatan guru mengawasi siswa menyelesaikan soal ulangan harian pada materi Turunan fungsi aljabar. Setelah itu hasil kerja siswa dianalisis untuk mengetahui kesalahan apa saja yang dilakukan untuk selanjutnya dilakukan wawancara untuk setiap tahapan kesalahan pemecahan masalah. Teknik analisis data yang digunakan dalam penelitian ini adalah Miles and Huberman dengan aktivitas analisis data meliputi reduction, display, dan verification, sedangkan uji keabsahan data dilakukan dengan triangulasi teknik.

\section{HASIL DAN PEMBAHASAN}

Hasil analisis kesalahan siswa dalam menyelesaikan soal ulangan harian matematika pada materi Turunan Fungsi Aljabar berdasarkan tahapan kesalahan yang dilakukan oleh siswa disajikan pada Tabel 1. Pada Tabel 1 menunjukkan bahwa keseluruhan siswa melakukan kesalahan pada tahap pengecekan kembali pada saat mengerjakan soal ulangan harian. Kesalahan ini dikarenakan siswa tidak memeriksa kembali jawaban yang telah mereka kerjakan. Hal ini dikarenakan dalam penyelesaian soal, siswa hanya mengunakan rumus/cara yang biasa dilakukan tanpa melihat kondisi soal atau prasyarat berlakunya. 
Tabel 1. Persentase Siswa yang Melakukan TahapKesalahan dalam Menyelesaikan Soal Ulangan Harian Turunan Fungsi Aljabar

\begin{tabular}{|c|c|c|c|c|c|c|c|c|}
\hline \multirow{3}{*}{$\begin{array}{c}\text { Nomor } \\
\text { Soal }\end{array}$} & \multicolumn{8}{|c|}{ Tahapan Kegiatan } \\
\hline & \multirow{2}{*}{\multicolumn{2}{|c|}{ Memahami Masalah }} & \multirow{2}{*}{\multicolumn{2}{|c|}{$\begin{array}{c}\text { Merencanakan } \\
\text { Penyelesaian }\end{array}$}} & \multirow{2}{*}{\multicolumn{2}{|c|}{$\begin{array}{c}\text { Menyelesaikan } \\
\text { Masalah }\end{array}$}} & \multirow{2}{*}{\multicolumn{2}{|c|}{ Pengecekan Kembal }} \\
\hline & & & & & & & & \\
\hline 1 & 2 & 10 & 1 & 5 & 16 & 80 & 20 & 100 \\
\hline 2 & 1 & 5 & 4 & 20 & 6 & 30 & 20 & 100 \\
\hline Rerata & \multicolumn{2}{|c|}{7,5} & \multicolumn{2}{|c|}{12,5} & \multicolumn{2}{|c|}{55} & \multicolumn{2}{|c|}{100} \\
\hline
\end{tabular}

Tabel 2 Persentase Kesalahan Siswa dalam Menyelesaikan Soal Ulangan Harian Turunan Fungsi Berdasarkan Tipe Kesalahan

\begin{tabular}{lcccc}
\hline \multicolumn{1}{c}{ Soal } & \multicolumn{4}{c}{ Tipe Kesalahan } \\
\cline { 2 - 5 } & Fakta (\%) & Konsep (\%) & Prinsip (\%) & Operasi (\%) \\
\hline Fungsi $\mathrm{f}(\mathrm{x})=\frac{1}{3} \mathrm{x}^{3}+3 \mathrm{x}^{2}+8 \mathrm{x}+1$ & 25 & 40 & 15 & 20 \\
turun pada interval .... & & & & \\
Suatu persegi panjang dengan & 30 & 45 & 0 & 25 \\
keliling $14 \mathrm{~cm}$, maka luas & & & & \\
maksimumnya adalah .... & & &
\end{tabular}

\begin{tabular}{lllll}
\hline Rerata & 27,5 & 42,5 & 7,5 & 22,5
\end{tabular}

Tabel 2 menunjukkan bahwa tipe kesalahan yang paling banyak dilakukan siswa dalam menyelesaikan soal ulangan harian adalah kesalahan konsep. Kesalahan konsep yang dilakuakn oleh siswa dikarenakan dalam penggunaan rumus untuk menyelesaiakn soal ulangan harian tidak menyesuaikan dengan kondisi yang berlaku. Pada kesalahan fakta yamg dilakukan oleh siswa, kekeliruan dalam menuliskan simbol. Kesalahan prinsip yang dilakuakn siswa terjadi karena siswa tidak mampu mneyebutkan syarat fungsi turun turun atau fungsi mencapai optimum. Kesalahan operasi disebabkan siswa siswa salah dalam melakukan perhitungan.

\section{Kesalahan dalam Memahami Masalah}

Kesalahan pada tahap memahami masalah dilakukan oleh dilakukan oleh 2 siswa yakni siswa TF02 dan TF11. Kedua siswa tersebut melakukan kesalahan pada tahap ini karena tidak menuliskan apa yang ditanyakan dalam soal. Siswa TF11 bahkan tidak memahami rumus turunan fungsi dengan benar. 


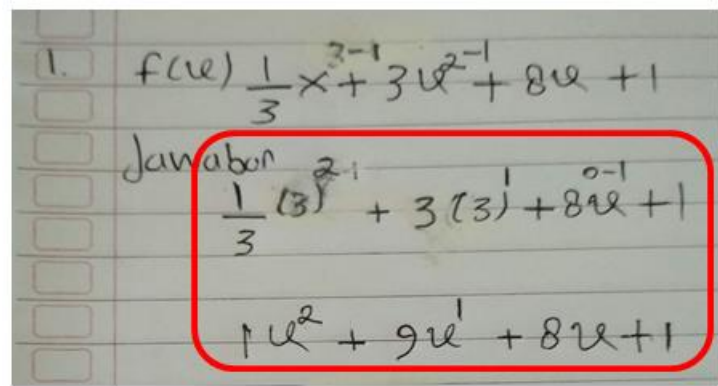

Gambar 2. Hasil Kerja Siswa TF11

Gambar 2 menunjukkan bahwa siswa TF11 melakukan kesalahan konsep dan operasi. Hal ini dipertegas dengan hasil wawancara, dengan transkrip sebagai berikut.

P : Pada soal nomor 1, mengapa Anda tidak menuliskan notasi turunannya?

TF11 : Karena terburu-buru dengan waktu, jadi saya langsung mengerjakan saja.

P : Lalu kenapa Anda juga tidak menuliskan variabel $\mathrm{x}$ pada jawaban?

TF11 : Saya lupa menggantinya

P : Lalu mengapa pada saat mengintegralkan masih salah koefisiennya?

TF11 : Saya lupa cara mengintegralkannya

Berdasarkan hasil wawancara diketahui bahwa siswa TF11 tidak menuliskan notasi turunan fungsi dan tetapi langsung mnegerjakannya karena terburu-buru oleh waktu. Namun setelah wawancara lebih lanjut diketahui bahwa siswa tidak tahu bagaimana mnegerjakan soal tersebut, bahkan siswa tidak menuliskan variabel pada fungsi. Menurut Naisunis dkk (2018) bahwa kesalahan konsep yang dilakukan siwa adalah karena siswa tidak memahami maksud ataupun makna soal dan juga ketidakmampuan siswa dalam melihat sifat suatu persamaan. Hal ini sejalan dengan pendapat Rahayuningsih dan Qohar (2014) bahwa kesalahan pemhamaman terjadi ketika siswa tidak mengetahui ataupun tidak menuliskan keterangan yang ada soal dan apa yang harus dilakukan untuk menyelesaiakan soal tersebut. Ketidakmampuan siswa TF11 dalam memahami masalah ataupun memaknai soal menyebabkan siswa tidak mampu menentukan strategi dalam menyelesaikan soal tersebut, sehingga kesalahan yang dilakaukan termasuk dalam kesalahan konsep.

\section{Kesalahan dalam Merencanakan Penyelesaian}

Terdapat 1 siswa yang melakukan kesalahan pada tahap merencanakan penyelesaian yaitu siswa TF06. Siswa tersebut melakukan kesalahan tahap kedua karena tidak menggunakan jnformasi yang ada untuk menyelesaikan masalah. Gambar 3 menunjukkan siswa TF06 melakukan kesalahan konsep dan fakta. Hasil analisis diperjelas dengan wawancara yang dilakukan kepada siswa TF06 dengan transkrip berikut.

P : Pada soal nomor 2, mengapa keliling persegi adalah $2 p+l$ ?

TF06 : Lha, yang benar apa, Pak?

P : Coba lihat gambarmu, tunjukkan mana 


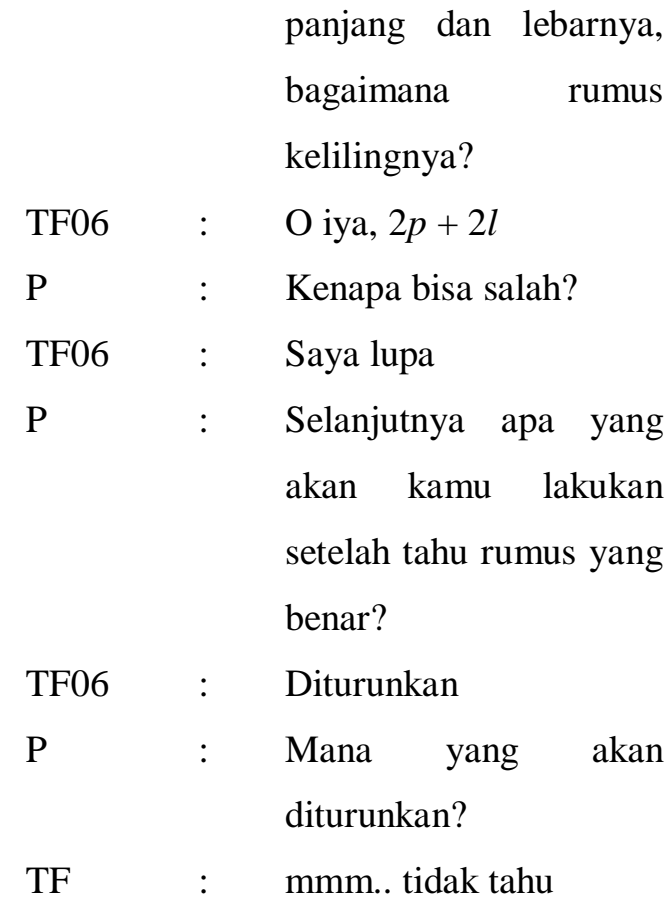

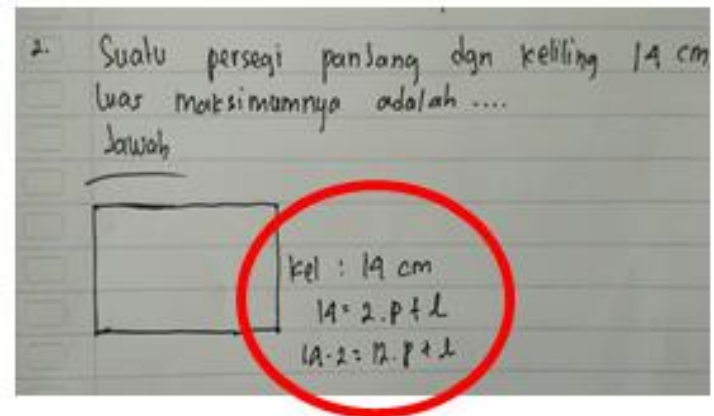

Gambar 3. Hasil Kerja Siswa TF06

\begin{abstract}
Berdasarkan hasil wawancara diperoleh bahwa siswa TF06 kurang bisa menggunakan informasi yang ada pada soal untuk menyelesaiakan masalah, sehingga kesalahan yang dilakukan adalah kesalahandalam merencanakan penyelesaian. Siswa TF06 melakukan kesalahan konsep karena tidak dapat melihat bentuk fungsi yang menyatakan luas persegi panjang yang berakibat pada kesalahan dalam menentukan
\end{abstract}

rumus fungsi yang akan diturunkan. Selain itu siswa TF06 juga melakukan kesalahan fakta karena tidak bisa menyebutkan rumus keliling persegi panjang dengan benar. Kesalahan ini terjadi karena kekurangcermatan atau kurang perhatian siswa terkait materi-materi sebelumnya

\section{Kesalahan dalam Menyelesaikan Masalah}

Kesalahan dalam menyelesaikan masalah dilakukan 16 siswa. Mayoritas siswa melakukan kesalahantahap ketiga karena tidak memperhatikan langkah penyelesaian dengan benar dalam menyelesaikan soal. Kesalahan tersebut ditunjukkan pada gambar 4.

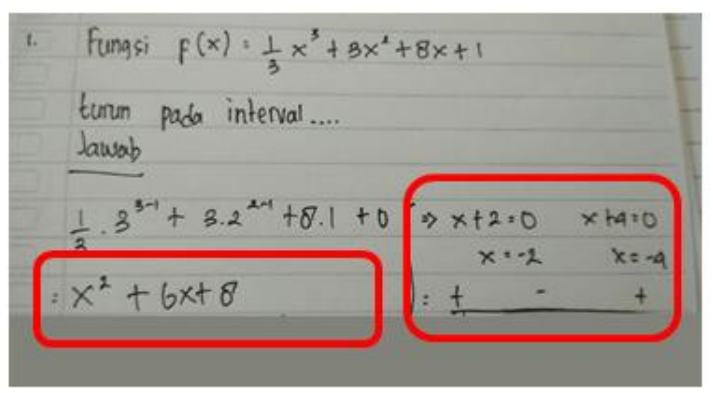

Gambar 4. Hasil Kerja Siswa TF07

Gambar 4 menunjukkan siswa melakukan kesalahan konsep. Hasil analisis ini diperjelas dengan wawancara yang dilakukan kepada siswa dengan transkrip sebagai berikut.

$\mathrm{P} \quad$ : Setelah menurunkan fungsinya , kenapa tanda pertidaksamaannya lebih dari?

TF07 : Bukankah contoh soalnya juga seperti itu?

P : Coba lihat soalnya, mintanya interval naik atau turun?

TF07 : Turun 
$\mathrm{P} \quad$ : Berarti $\mathrm{f}^{\prime}(\mathrm{x})$ harus bagaimana?

TF : Bagaimana ya...??

\section{Berdasarkan hasil wawancara} diketahui bahwa siswa tidak menggunakan langkah-langkah penyelesaian masalah dengan benar. Kesalahan yang dilakukan merupakan kesalahan konsep, karena siswa tidak memahami tentang penggunaan turunan fungsi untuk menentukan interval kemonotonan fungsi. Selain itu, dapat dilihat bahwa siswa kurang teliti dalam mengerjakan soal, siswa terbalik dalam meletakkan bilangan pada garis bilangan yang berakibat pada hasil akhir yang diperoleh.

\section{Kesalahan dalam Pengecekan Kembali}

Tahapan pengecekan kembali dalam langkah pemecahan masalah, dilakukan oleh seluruh siswa dalam menyelesaikan soal ulangan harian, sehingga seluruh siswa melakukan kesalahan ini hal ini dipertegas dengan hasil wawancara yang dilakukan kepada dua orang siswa yaitu TF18 dan TF20 dengan transkrip sebagai berikut.

P : Apakah kalian melakukan memeriksa kembali jawaban setelah mengerjakan soal-soal?

TF18 : Saya tidak terbiasa, jadi begitu selesai langsung saya kumpulkan.

TF20 : Karena waktunya sudah habis

Berdasarkan hasil wawancara dengan siswa diperoleh bahwa siswa tidak melakukan pengecekan kembali disebabkan tidak terbiasa melakukan dan keterbatasan waktu.
Keterbatasan waktu ini dikarenakan siswa masih sibuk mengejakan soal yang berarti siswa membutuhkan waktu yang lenih lama dari yang tersedia. Hal ini mengindikasikan siswa elum menguasai materi dengan baik.

\section{KESIMPULAN DAN SARAN}

Berdasarkan hasil penelitian diperoleh kesimpulan bahwa kesalahan-kesalahan yang dilakukan siswa dalam pemecahan masalah pada materi Turunan Fungsi meliputi 1) hasil penelitian ini adalah kesalahan yang dilakukan siswa pada tahap memahami masalah 7,5\%, kesalahan tahap merencanakan penyelesaian 12,5\%, kesalahan tahap menyelesaikan masalah 55\%, dan kesalahan tahap pengecekan kembali 100\%. 2) Berdasarkan tipe kesalahan diperoleh bahwa siswa melakukan kesalahan fakta 27,5\%, kesalahan konsep 42,5\%, kesalahan prinsip $37,5 \%$, dan kesalahan operasi 22,5\%. 3) Solusi yang ditawarkan oleh peneliti adalah agar siswa terbiasa melakukan pengecekan kembali. Hal ini diperkuat dengan pemenatapan konsep sehingga siswa mampu memanajemen waktu dalam menyelesaikan soal.

Berdasarkan kesimpulan di atas, maka peneliti menyarankan agar dalam kegiatan belajar mengajar pada masalah turunan fungsi dapat meperhatikan kemampuan dasar turunan dan fungsi. Diharapkan kesalahan-kesalahan mendasar dapat ditekan pada saat memasuki materi konseptual yang utama. 


\section{DAFTAR PUSTAKA}

Abdullah, A. H., Abidin, N.L. Zainal, \& Ali, Marlina. (2015). Analysis of Students' Errors in Solving Higher Order Thinking Skills (HOTS) Problems for Topic of Fraction. Asian Social Science. Vol. 11, No. 21.

Amir, M.F. (2015). Analisis Kesalahan Mahasiswa PGSD Universitas Muhammadiyah Sidoarjo dalam Menyelesaikan Soal Pertidaksamaan Linear. Jurnal Edukasi. Vokume 2 No. 1. Hal.131-145

Arikunto, S. (2010). Prosedur Penelitian (Suatu Pendekatan Praktik). Bandung: Rineka Cipta.

Herholdt, R. \& Sapire, I.. 2014. An Error Analysis in the Early Grades Mathematics - A Learning Opportunity? South African Journal of Childhood Education - 4(1): 42 -60. ISSN: $2223-7674$

Mahmudah, K. S., Sunismi, S., \& Fathani, A. H. (2019). Pengembangan Bahan Ajar Matematika dengan Pendekatan Pendidikan Matematika Realistik Indonesia pada Materi Sistem Persamaan Linier Dua Variabel. Jurnal Komunikasi Pendidikan, 3(1), 33-41.

Naisunis, Y.P, Taneo, P. N. L. \& Daniel, F. (2018). Analisis Kesalahan Mahasiswa
Dalam Pemecahan Masalah Pada Mata Kuliah Persamaan Diferensial. Edumatica. Vol. 8 No. 2, Oktober 2018. Hal.107-119

Permendikbud Nomor 20 Tahun 2016 tentang Standar Kompetensi Lulusan

Priansa, D.J. (2015). Manajemen Peserta Didik dan Model Pembelajaran. Bandung. Alfabeta

Rahayuningsih, P. \& Qohar. (2014). Analisis Kesalahan Menyelesaikan Soal cerita Sistem Persamaan Linear Dua Variabel (SPLDV) dan Scaffoldingnya Berdasarkan Analisis Kesalahan Newman pada Siswa Kelas VIII SMP Negeri 2 Malang. Jurnal Pendidikan Matematika dan Sains. Vol. 2 No.2. Hal. 109-116

Rakhmat, C dan Suherdi D. (2001). Evaluasi Pengajaran. Bandung : Maulana

Slameto. (2003). Belajar dan Faktor-Faktor yang Mempengaruhinya. Jakarta: Rieneka Cipta

Widodo, S. A. (2013). Analisis Kesalahan Dalam Pemecahan Masalah Divergensi Tipe Pembuktian Pada Mahasiswa Matematika. Jurnal Pendidikan dan Pengajaran. Vol. 46, No.2. Hal: 106-113.

Winkel, WS. (1991). Psikologi Pendidikan dan Evaluasi Belajar. Jakarta : Gramedia 